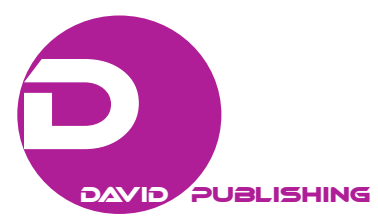

\title{
Analysis of the Moderator Effect of RMB Exchange Rate on Export - The Case of Guangdong Province in China
}

\author{
Yan Zhang \\ Macau University of Science and Technology, Macau, China \\ Beijing Normal University, Zhuhai, China \\ Yan Zhou \\ Macau University of Science and Technology, Macau, China \\ Zhuhai College of Jilin University, Zhuhai, China \\ Haojia Chen \\ Beijing Normal University, Zhuhai, China
}

\begin{abstract}
An important limitation of the research literatures which study the effect on the export of the real effective exchange rates is the lack of application of interaction or moderator effect among the independent variables. To remedy this lacuna, the authors developed a model in which real effective exchange rate moderated the effect of import and utilization of foreign capital on export. The sample comprised 11 years' data in Guangdong China. The result showed that real effective exchange rate of RMB affected the export by interacting with utilization of foreign capital. Moreover, to some degree, the real effective exchange rate can also act as moderator between import and export.
\end{abstract}

Keywords: import, export, real effective exchange rate (REER), utilization of foreign capital, moderator effect

\section{Introduction}

The real effective exchange rate has been a hot issue since the worldwide economy develops. Many scholars studied the relationship between it and trade export. The authors want to find out how it affects the exports of Guangdong province of China, based on the direct effect and moderator effect of the RMB exchange rate, by analyzing the data (2004-2014) of Guangdong Province.

\section{Literature Review}

The research literatures studying the effect on the export of the real effective exchange rates focus mainly on two fields. One is the discussion whether the Marshall-Lerner condition holds or not. Dornbusch (1976) and

Yan Zhang, lecturer, School of Business, Macau University of Science and Technology, and International Business Faculty, Beijing Normal University Zhuhai Campus, China.

Yan Zhou, lecturer, School of Business, Macau University of Science and Technology, and Department of International Trade and Finance, Zhuhai College of Jilin University, China.

Haojia Chen, graduate student, International Business Faculty, Beijing Normal University Zhuhai Campus, China.

Correspondence concerning this article should be addressed to Yan Zhou, School of Business, Macau University of Science and Technology, Macau, China. 
Bahmani-Oskooee (1998) thought it does not hold. While Knigman and Baldwin (1987), Moffett (1989), and Marquez (1989) thought the opposite. The other researchers such as Rose and Yellen (1989), Backus, Kehoe, and Kydland (1994) tried to confirm that the effect of the real effective exchange is coherence with the J curve effect from the long term.

Chinese scholars contributed on these two fields too. Chen (2007) studied the overall effect of effective rate of exchange on export and time validity of the J curve. Zhang and He (2009) analyzed the long-run equilibrium relations between Guangdong Province's exports and its imports, foreign direct investment (FDI), the economic growth of the importing countries, the nominal exchange rate of RMB, and other factors. For the method of current studies on real effective exchange rate (REER), mainly co-integration analysis, simple OLS, and VAR (2000) are applied. An important limitation of this literature is the lack of application of interaction or moderator effect among the independent variables. The central objective of this paper is to remedy to this lacuna and to build a more comprehensive model to analyze the various influence factors on export.

\section{About Moderator Variable and Moderator Effect}

According to James and Brett (1984), a moderator effect as in Figure 1 is an effect of a predictor variable (X) on a criterion (Y) depending on a third variable (M) the moderator. It is also labelled interaction effect, which provides information on whether the relationship between the two variables is contingent upon the value of a third variable. In other words, an interaction effect hypothesis states that the relationship between the two variables, or the effect of one variable on a second one, depends on the value of a third (moderator) variable.

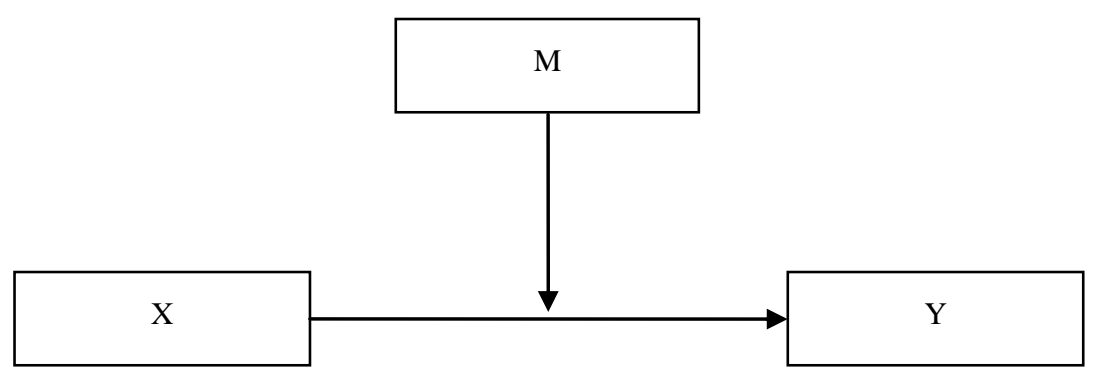

Figure 1. The moderating effect model.

The regression model with interaction is $\hat{Y}=\beta_{0}+\beta_{1} X+\beta_{2} M+\beta_{3} X \cdot M$ and there are two equivalent ways to evaluate whether an interaction is present:

(1) Test whether the coefficient $b_{3}$ differs significantly from zero;

(2) Test whether the increment in the squared multiple correlation $\left(\Delta \mathrm{R}^{2}\right)$ given by the interaction is significantly greater than zero.

\section{The Empirical Model}

According to Lain and Li (2008), and Zhang (2014), FDI has a positive effect on export and import. He, Sun, and Liu (2009) studied on exchange rate volatility's impact on Chinese manufacture industry's export, and took import, REER, technology improvement, world GDP, and FDI as factors influencing export of manufacture industry. Zhou and Tian (2003) demonstrated an empirical analysis and verified the influence of the four factors import, utilization of foreign capital, trader partner countries' economic growth, and exchange 
rate on export. The authors agreed with their argument that FDI was calculated based on contract amount, however, contract amount might not be available in total in the same year, or the investment cycle might be longer than one year. Thus the authors chose to apply the data of actual usage of foreign capital to more accurately depict the relationship between foreign capital and export.

Based on the above literatures and argument, the authors consider REER, import, the weighted GDP of six major import countries (WGDP), and utilization of foreign capital (UFC) as four independent variables, which impact the dependent variable of export. Besides, REER is employed as a moderator variable as well in the model (see Figure 2).

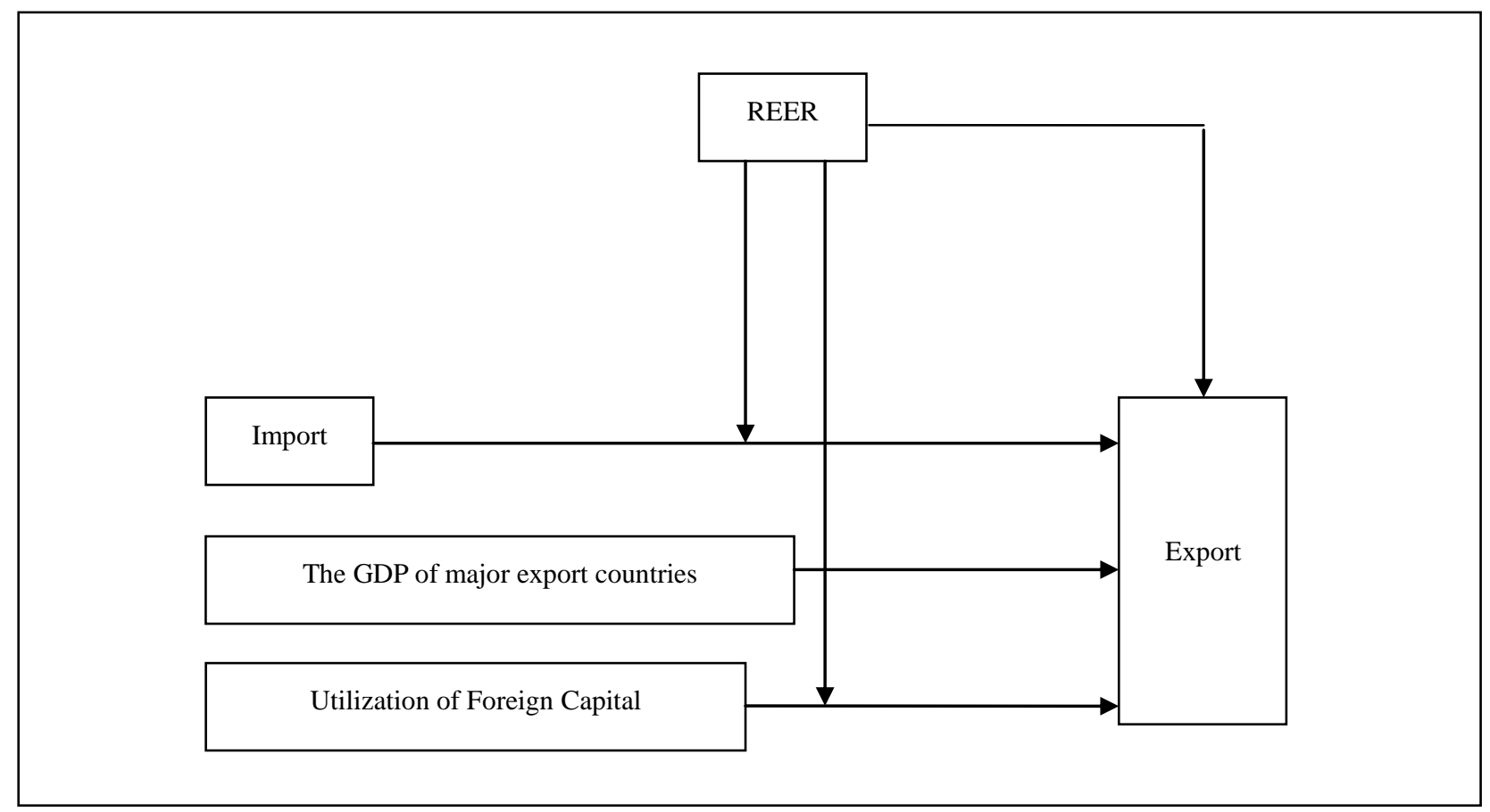

Figure 2. The moderating effect in export model.

Export $_{t}=\beta_{0}+\beta_{1}$ Import $_{t-1}+\beta_{2} U F C_{t-1}+\beta_{3} W_{G D P_{t-1}}+\beta_{4}$ REER $_{t}+\beta_{5}$ REER $_{t} * \operatorname{Import}_{t-1}+\beta_{6}$ REER $_{t} * U F C_{t-1}+\varepsilon$

\section{Data}

Export is the annual export of Guangdong province from year 2004 to 2014; import is the annual import of Guangdong province from year 2003 to 2013.

REER is real effective exchange rates of RMB from year 2004 to 2014; WGDP is the weighted average GDP of six major import countries from Guangdong province from year 2003 to 2013; UFC is utilization of foreign capital of Guangdong Province from year 2003 to 2013; REER data are collected from World Bank database.

Export, Import, and UFC data are gathered from Guangdong Statistical Yearbook. WGDP data are collected from World Bank database and Guangdong Statistical Yearbook, then calculated based on the weights of import of that country to total import of six countries.

\section{Hypotheses}

H1: The import of Guangdong has a positive effect on the export so that export will be higher if import is 
higher;

H2: Utilization of foreign capital has a direct effect on export;

H3: The weighted GDP has a direct effect on export;

H4: In the current year, REER has a direct effect on the export;

H5: In the current year, REER is moderating the relationship between import and export;

H6: There is an interaction effect between UFC and REER in predicting export.

\section{Result}

\section{Regression Analysis}

Table 1

The Regression Result 1

\begin{tabular}{|c|c|c|c|c|c|c|}
\hline \multicolumn{7}{|c|}{ Coefficients } \\
\hline \multirow[t]{2}{*}{ Model } & & \multicolumn{2}{|c|}{ Unstandardized coefficients } & \multirow{2}{*}{$\begin{array}{l}\text { Standardized } \\
\text { coefficients } \\
\text { Beta }\end{array}$} & \multirow[t]{2}{*}{$t$} & \multirow{2}{*}{ Sig. } \\
\hline & & $\mathrm{B}$ & Std. error & & & \\
\hline \multirow{5}{*}{1} & (Constant) & 427778.637 & 1833.678 & & 233.290 & 0.000 \\
\hline & Importc & 1.116 & 0.090 & 0.720 & 12.448 & 0.000 \\
\hline & UFCc & 9.464 & 2.485 & 0.259 & 3.808 & 0.009 \\
\hline & WGDPc & 0.010 & 0.014 & 0.015 & 0.716 & 0.501 \\
\hline & REERc & 470.116 & 551.204 & 0.037 & 0.853 & 0.426 \\
\hline \multirow{6}{*}{2} & (Constant) & 424402.313 & 2949.995 & & 143.865 & 0.000 \\
\hline & Importc & 1.130 & 0.084 & 0.729 & 13.481 & 0.000 \\
\hline & UFCc & 9.710 & 2.314 & 0.266 & 4.197 & 0.009 \\
\hline & WGDPc & 0.018 & 0.014 & 0.026 & 1.259 & 0.264 \\
\hline & REERc & 250.195 & 535.176 & 0.020 & 0.468 & 0.660 \\
\hline & ImportReer & 0.003 & 0.002 & 0.021 & 1.401 & 0.220 \\
\hline \multirow{7}{*}{3} & (Constant) & 427836.021 & 2146.349 & & 199.332 & 0.000 \\
\hline & Importc & 1.118 & 0.052 & 0.721 & 21.557 & 0.000 \\
\hline & UFCc & 13.198 & 1.836 & 0.362 & 7.187 & 0.002 \\
\hline & WGDPc & -0.012 & 0.013 & -0.018 & -0.944 & 0.399 \\
\hline & REERc & -837.830 & 488.684 & -0.066 & -1.714 & 0.162 \\
\hline & ImportReer & -0.019 & 0.008 & -0.121 & -2.527 & 0.065 \\
\hline & UFCReer & 0.442 & 0.146 & 0.138 & 3.021 & 0.039 \\
\hline
\end{tabular}

Note. Dependent Variable: Export.

Table 2

The Regression Result 2

\begin{tabular}{|c|c|c|c|c|c|c|}
\hline \multicolumn{7}{|c|}{ Excluded Variables $^{\mathrm{a}}$} \\
\hline \multirow{2}{*}{ Model } & & \multirow{2}{*}{ Beta in } & \multirow{2}{*}{$\mathrm{t}$} & \multirow{2}{*}{ Sig. } & \multirow{2}{*}{ Partial correlation } & Co linearity statistics \\
\hline & & & & & & tolerance \\
\hline \multirow{2}{*}{1} & ImportReer & $0.021^{\mathrm{b}}$ & 1.401 & 0.220 & 0.531 & 0.591 \\
\hline & UFCReer & $0.025^{\mathrm{b}}$ & 1.949 & 0.109 & 0.657 & 0.652 \\
\hline 2 & UFCReer & $0.138^{\mathrm{c}}$ & 3.021 & 0.039 & 0.834 & 0.024 \\
\hline
\end{tabular}

Note. a. Dependent Variable: Export.

b. Predictors in the Model: (Constant), REERc, WGDPc, Importc, UFCc.

c. Predictors in the Model: (Constant), REERc, WGDPc, Importc, UFCc, ImportReer. 


\section{Conclusion}

From the regression result above, the authors observe that the different factors of import, utilization of foreign capital, and REER affect the export in different degree. In this paper, the authors focus on the effect of REER only.

The direct effect of REER on export: It is shown by the numerical result that the direct effcet of REER on export is not as great ( $\beta=-837.830, t=-1.714$ ) as it is expected. The reason might be that the authors consider the aggregated export here of all the industries. Some scholars have found that REER has almost no direct effect on export in the high-tech industries. In Guangdong Province, high and new-tech products are of $35 \%-40 \%$ of overall export from 2004 to 2014. The high export ratio industries with high technology have averaged the total effect. This is the future direction that the authors will make further emprical analysis on the market segments in the future research.

(1) The indirect effect of REER on the relationship between import and export: The joint effect of REER and import on export was statistically significant $(\beta=-0.019, t=-2.527)$. Thus, the authors conclude that REER serves as a moderator of the effect of import on export. REER has a negative effect on the relationship between import and export so that with a higher import, the export will be lower.

(2) The indirect effect of REER on the relationship between UFC and export: REER and UFC have interaction effect on export, based on the regression analysis ( $\beta=0.442, t=3.021$ ). REER has a positive effect on the relationship between UFC and export so that with a higher UFC, export will be higher.

\section{Limitations and Future Research Directions}

Although the authors collected data from government yearbook, their sample data are not treated differently in subdivion markets. It is possible that, in high-tech industries, REER does not have significant effect on export. Hence future research should examine the market segments in more detail.

Moreover, one of their independent variables WGDP is not siginificant in the test, a careful next step would be to conduct an emperical study to examine the relationship between WGDP and export.

\section{References}

Bahmani-Oskooee, M., \& Niroomand, F. (1998). Long run price elasticties and the Marshall Lerner condition revisied. Economics Letters, 61(1), 101-109.

Chen, X. B. (2007). The impact of real exchange rate on China's import and export trade 1997-2006. Asia Pacific Finance, 3, 57-63.

Dackus, D. K., Kehoe, P. J., \& Kydland, F. E. (1994). Dynamics of the trade balance and the terms of trade: The J curve. The American Economic Review, 84(1), 84-103.

Dornbusch, R. (1976). Expectation and exchange rate dynamics. Journal of Political Economy, 84(12), 1161-1176.

He, Z., Sun, L., \& Liu, X. Y. (2009). Analysis of RMB exchange rate effect on export of China manufacturing industries based on moderate mode. Journal of Studies in Science of Science, 2, 209-213.

James, L. R., \& Brett, J. M. (1984). Mediators, moderators and tests for mediation. Journal of Applied Psychology, 69(2), $307-321$.

McCarthy, J. (2000). Pass through of exchange rates and import prices to domestic inflation in some industrialized economies. Research Department Federal Reserve Bank of New York.

Krugman, P., \& Baldin, R. E. (1987). The persistence of the US trade deficit. Brookings Papers on Economic Activity, 1, 1-55. Lian, \& Li. (2008). The dynamic analysis on the relationship between China's FDI, foreign trade and economic growth. Foreign Trade, 1.

Moffett, M. H. (1989). The J curve revisited: An empirical 1 examination for the united states. Journal of International Money and Finance, 8, 425-444. 
Marque, Z. J. (1990). Bilateral trade elasticities. The Review of Economics and Statistics, 72(1), 70-77.

Rose, A. K., \& Yellen, J. L. (1989). Is there a J curve? Journal of Monetary Economics, 24(1), 53-58.

Zhao, Y., \& He, J. F. (2009). An empirical analysis of the factors affecting the export of foreign trade in Guangdong province since the reform and opening up. Special Zone Economy, 2, 24-25.

Kevin Zhang, H. L. (2014). How does FDI affect a host country's export performance? The case of China.

Zhou, C. Y., \& Tian, F. (2003). Journal of Contemporary Finance \& Economics, 12, 92-94. 